\title{
Molecular detection of Ehrlichia canis in dogs from the Pantanal of Mato Grosso State, Brazil
}

\author{
Detecção molecular de Ehrlichia canis em cães do Pantanal do Mato Grosso, Brasil
}

Luana Gabriela Ferreira dos Santos ${ }^{1,2}$; Andréia Lima Tomé Melo ${ }^{1,2}$; Jonas Moraes-Filho ${ }^{3}$; Rute Witter²; Marcelo Bahia Labruna ${ }^{3}$; Daniel Moura de Aguiar ${ }^{2 *}$

\author{
${ }^{1}$ Programa de Pós-graduaçáo em Ciências Veterinárias, Faculdade de Agronomia, Medicina Veterinária e Zootecnia, \\ Universidade Federal de Mato Grosso - UFMT, Cuiabá, MT, Brasil \\ ${ }^{2}$ Laboratório de Virologia e Rickettsioses, Hospital Veterinário, Universidade Federal de Mato Grosso - UFMT, Cuiabá, MT, Brasil \\ ${ }_{3}^{3}$ Departamento de Medicina Veterinária Preventiva e Saúde Animal, Faculdade de Medicina Veterinária e Zootecnia, \\ Universidade de São Paulo - USP, São Paulo, SP, Brasil
}

Received August 13, 2012

Accepted December 1, 2013

\begin{abstract}
The present study evaluated the presence of Ehrlichia DNA in the blood samples of 320 dogs from the urban and rural areas of the municipality of Poconé, Pantanal region, Mato Grosso state, by Polymerase Chain Reaction (PCR), targeting the ehrlichial $d s b$ gene. Risk factors for infection in dogs were also evaluated. Forty-eight (15\%, 95\% CI: $11.4-19.5 \%)$ dogs were positive: 25 (15.6\%, 95\% CI: 10.4-22.2\%) from the urban area and 23 (14.4\%, 95\% CI: 9.3-20.8\%) from the rural area ( $>$ > 0.05). Partial DNA sequence obtained from PCR products of 18 samples from the urban area and 16 samples from the rural area were $100 \%$ identical to E. canis from Brazil and the USA. This study reports the first $E$. canis molecular detection in dogs from the northern Pantanal region.
\end{abstract}

Keywords: Dogs, tick borne disease, Ehrlichia canis, Anaplasmataceae, Poconé, Brazil.

\section{Resumo}

O presente estudo avaliou a presença de DNA de Ehrlichia spp. em 320 cáes das áreas urbana e rural do município de Poconé, região do Pantanal de Mato Grosso, pela PCR visando o gene dsb. Os fatores de risco para a infecção em cães também foram avaliados. Quarenta e oito (15\%, IC 95\%: 11,4-19,5\%) cães foram positivos, 25 (15,6\%, IC 95\%: 10,4-22,2\%) da área urbana e 23 (14,37\%, 95\% CI: 9,3-20,8\%) da área rural (P > 0,05). Sequências parciais de DNAs obtidos a partir de produtos da PCR de 18 amostras da área urbana e 16 da área rural foram $100 \%$ idênticas a $E$. canis do Brasil e EUA. Este estudo relata a primeira detecção molecular de E. canis em cães da região norte do Pantanal.

Palavras-chave: Cães, ectoparasitos, Ehrlichia canis, Anaplasmataceae, Poconé, Brasil.

\section{Introduction}

Bacteria of the genus Ehrlichia are tick-borne agents that cause significant diseases in domestic animals (McBRIDE; WALKER, 2010; DUMLER et al., 2001). In Brazil, Ehrlichia canis is the agent of canine monocytic ehrlichiosis (CME), a canine disease of nearly worldwide distribution, transmitted by the tick Rhipicephalus sanguineus (HARRUS; WANER, 2011; VIEIRA et al., 2011). In North America, dogs can also be infected by Ehrlichia chaffeensis and Ehrlichia ewingii, which are important agents of zoonoses vectored by Amblyomma ticks in that continent (McBRIDE; WALKER, 2010).

\section{${ }^{*}$ Corresponding author: Daniel Moura de Aguia}

Laboratório de Virologia e Rickettsioses, Hospital Veterinário,

Universidade Federal de Mato Grosso - UFMT, Av. Fernando Corrêa,

2367, Boa Esperança, CEP 78060-900, Cuiabá, MT, Brasil

e-mail: danmoura@ufmt.br
Some studies emphasized the possibility that Ehrlichia species other than E. canis are circulating in Brazil, especially in the Pantanal area, a large periodically wetland area of Brazil that harbors high diversity of mammals and ticks (ALHO et al., 1987; BECHARA et al., 2000). Melo et al. (2011) reported high prevalence of anti-Ehrlichia antibodies in domestic dogs from the municipality of Poconé, a northern sub-region of Pantanal. Because some of these seropositive dogs were not infested by $R$. sanguineus ticks (they were rather infested by Amblyomma ticks), the authors speculated on the possible occurrence of different Ehrlichia species infecting dogs in the region. In the southern area of Pantanal, Widmer et al. (2011) reported a novel ehrlichial agent (genetically related to Ehrlichia ruminantium) infecting free-living jaguars (Panthera onca) and ticks. Additionally, E. chaffeensis was molecularly detected in Brazilian marsh deers 
(Blastocerus dichotomus) in a wetland area borderline of Mato Grosso do Sul and São Paulo states (MACHADO et al., 2006). Other reports include molecular detection of Ehrlichia sp. in Brazilian wild captive carnivore species maintained in several zoos in Brazil (ANDRÉ et al., 2010, 2012).

Since serological tests cannot distinguish between infection by E. canis and other Ehrlichia species (KELLY et al., 1994; ALLSOPP; ALLSOPP, 2001), the present study aimed to evaluate the presence of Ehrlichia species by molecular tools in blood samples of dogs from the municipality of Poconé, Pantanal region, Brazil, where higher canine seroprevalence of Ehrlichia spp. has been recently reported (MELO et al., 2011).

\section{Materials and Methods}

\section{Study site and blood collection}

The study was conducted in the municipality of Poconé $\left(16^{\circ} 15^{\prime} \mathrm{W}\right.$ and $\left.56^{\circ} 37^{\prime} \mathrm{S}\right), 100 \mathrm{~km}$ southwest of Cuiabá, the capital of Mato Grosso state. Samples were obtained between July and September 2009 by Melo et al. (2011), who evaluated the prevalence of antibodies against Rickettsia spp. and E. canis, as well as the presence of ectoparasites in dogs from the related area. In the urban areas, samples were collected from 160 dogs of all (12) neighborhoods ( -13 dogs per neighborhood), whereas in the rural areas, samples were obtained from 160 dogs of 25 farms $(-4.7$ dogs per farm) and three rural communities ( -14 dogs per community; Figure 1). The blood samples were collected from the jugular vein in vacuum tubes with ethylenediamine tetraacetic acid (EDTA) and stored in $1.5 \mathrm{~mL}$ microtubes at $-20{ }^{\circ} \mathrm{C}$ until processing. A questionnaire was given to each dog owner in order to obtain information related to age, sex, ectoparasites infestation, habitat, and hunting practice. The sample protocol was approved by the Ethics Committee for Animal Research of the Federal University of Mato Grosso (Protocol number 23108.019742/09-9).

\section{Nucleic acid extraction and polymerase chain reaction}

DNA was extracted from blood samples in EDTA solution using an UltraClean Blood DNA Isolation kit (MO BIO Laboratories Inc., Carlsbad, CA) according to the manufacturer's instructions. The DNA samples were initially processed by a PCR protocol designed to amplify a 409-bp fragment of the $d s b$ gene of Ehrlichia genus (LABRUNA et al., 2007) using primers 330 forward (5' GATGATGTCTGAAGATATGAAACAAAT 3') and 728 reverse

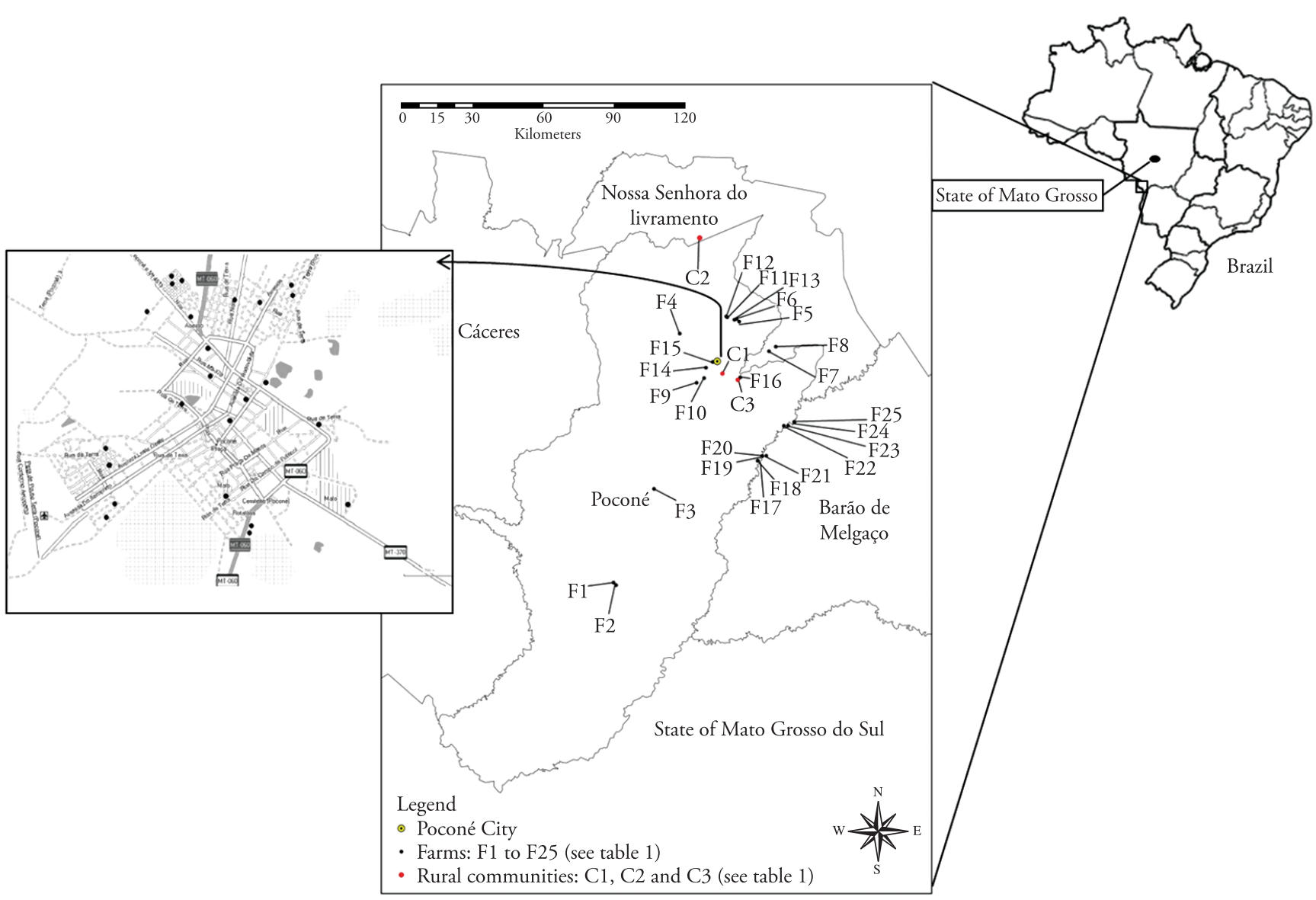

Figure 1. Poconé and neighboring municipalities of Mato Grosso State, Brazil, indicating the urban area (city of Poconé), 25 farms, and 3 rural communities where dogs were sampled in the present study. In the urban area, places where positive dogs were sampled are indicated $(\bullet)$. 
(5' CTGCTCGTCTATTTTACTTCTTAAAGT 3)'. In addition, samples were also tested by a heminested-PCR targeting portions of 401-bp (1st reaction) and 349-bp ( $2^{\text {nd }}$ reaction) of the $d s b$ gene of all Ehrlichia species (ALMEIDA, 2011, Table 1). PCR products were analyzed by $1.5 \%$ agarose gel electrophoresis stained with ethidium bromide and examined by UV transillumination. Samples that yielded amplicon of the expected size by the above PCR protocols were subjected to a $d s b$ real-time PCR in order to confirm previous findings through an E. canis-specific probe assay, as previously described (DOYLE et al., 2005). In all reactions, a positive control (DNA of E canis-infected DH82 cells) as well as three negative controls (water) were included.

\section{Purification and genetic sequencing}

Conventional PCR products were purified using illustra GFX PCR DNA and Gel Band Purification Kit (GE Healthcare Bio-Sciences) according to manufacturer's instructions and sequenced directly using the primers Dsb-380 and Dsb-720 and Big Dye Kit (Applied Biosystems), according to manufacturer's instructions in ABI-PRISM 3100 Genetic Analyzer. The sequences were edited using SeqMan software (Lasergene, DNAstar, Madison, WI USA.) and similarity was analyzed using the program Basic Local Alignment Search Tool (BLAST two sequences analysis) (ALTSCHUL et al., 1990) to check for homology with corresponding sequences available in GenBank.

\section{Statistical analysis}

Prevalence values were calculated with a 95\% confidence interval. The association between Ehrlichia infection in dogs and the independent variables was performed by the Chi-Square test $\left(\chi^{2}\right)$, or Fisher's exact test when necessary. In the rural area, the presence of tick species in farms was evaluated as another variable. Variables that presented $P \leq 0.05$ were considered significant. The statistical software EPIINFO 7.0 was used for analysis.

\section{Results and Discussion}

Forty-eight dogs (15\%; 95\% CI: 11.4- 19.5\%) tested positive by both PCR and heminested-PCR, targeting portions of the ehrlichial $d s b$ gene in order to increase the diagnostic sensitivity (ALMEIDA, 2011). All 48 dogs from the urban and rural areas were shown by $d s b$ real-time PCR to contain E. canis DNA. Partial DNA sequences (250-bp) of 34 PCR-positive samples were generated; they were identical to each other and 100\% identical to the multiple corresponding $E$. canis sequences available in GenBank (AF403710, CP000107, DQ460715, DQ460716). $D s b$ gene sequence from the identified $E$. canis isolate in this study was deposited in GenBank and assigned the nucleotide accession number JQ419757.1.

In the urban area, 25 dogs (15.6\%; 95\% CI: 10.4-22.2\%) were positive, whereas in the rural area 23 dogs (14.4\%; CI: 9.3$20.8 \%)$ from nine farms $(36.0 \%)$ and all communities (100\%) were positive (Table 2). However, no statistical difference for E. canis positivity between urban and rural dogs was observed $(\mathrm{P}>0.05)$. Similar results were observed in the previous study by Melo et al. (2011), who detected, by IFAT, positive reaction against Ehrlichia spp. in 227 (70.9\%) dogs: 119 (74.3\%) from urban areas and 108 (67.5\%) from rural areas ( $\mathrm{P}>0.05)$. Additionally, $R$. sanguineus was present in all urban neighborhoods, and was not found in only three farms of the currently PCR positive dogs (Table 2); however, the presence of $R$. sanguineus ticks on the dogs studied was not considered a risk factor for $E$. canis infection in the farms. Nevertheless, Melo et al. (2011) reported that some of these rural dogs were frequently taken to urban or suburban environments, which may explain the positivity for $E$. canis regardless of the presence of $R$. sanguineus in the farm. On the other hand, Amblyomma spp. were associated $(\mathrm{P}<0.05)$ with the presence of PCR-negative dogs in the farms, emphasizing the relevance of $R$. sanguineus in the transmission of $E$. canis to dogs (HARRUS; WANER, 2011). Breed, sex and age were not associated with PCR positivity. Melo et al. (2011), studying this same dogs, reported greater frequency of seropositive dogs as they become older, probably due to a higher chance of becoming infested with ticks over time.

Table 1. Ehrlichia species and primer sequences*.

\begin{tabular}{|c|c|c|c|}
\hline $\begin{array}{c}\text { Ehrlichia species } \\
\text { (Genbank accession } \\
\text { number) }\end{array}$ & $\begin{array}{c}\text { Primer Dsb-330 (forward) } \\
\text { 5'-3' }\end{array}$ & $\begin{array}{c}\text { Primer Dsb- } 720 \text { (reverse) } \\
5^{\prime}-3^{\prime}\end{array}$ & $\begin{array}{c}\text { Primer Dsb - } 380 \text { (forward) } \\
5^{\prime}-3^{\prime}\end{array}$ \\
\hline Primer sequence & GATGATGCTTGAAGATATSAAACAAAT & CTATTTTACTTCTTAAAGTTGATAWATC & ATTTTTAGRGATTTTCCAATACTTGG \\
\hline $\begin{array}{l}\text { E. chaffeensis } \\
\text { (AF403711) }\end{array}$ & А................ & A & …А..... \\
\hline $\begin{array}{c}\text { E. canis } \\
\text { (AF403710) }\end{array}$ & А.................. & $\ldots$ & 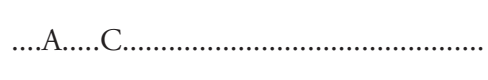 \\
\hline $\begin{array}{c}\text { E. muris } \\
\text { (AY236484) }\end{array}$ & А & 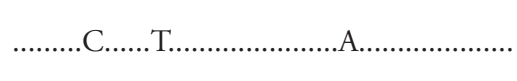 & ...А....С.С................Т................ \\
\hline $\begin{array}{l}\text { E. ruminantium } \\
(\text { AF308669) }\end{array}$ & А & 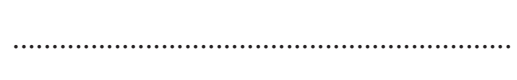 & $\cdots$ \\
\hline $\begin{array}{l}\text { Anan strain } \\
\text { (AY236485) }\end{array}$ & …...... & ........... & ‥А \\
\hline
\end{tabular}

*Primers used in heminested-PCR as follows: Dsb-330 and Dsb-720, in the first reaction; Dsb-380 and Dsb-720, in the second reaction. 
Table 2. Detection of Ehrlichia canis DNA in dogs from the Pantanal and results of serological and ticks data in the municipality of Poconé

\begin{tabular}{|c|c|c|c|c|c|}
\hline \multirow{2}{*}{ Locality* } & \multirow{2}{*}{$\begin{array}{c}\text { No. tested } \\
\text { dogs }\end{array}$} & \multicolumn{2}{|c|}{ Detection of Ehrlichia DNA } & \multirow{2}{*}{$\begin{array}{l}\text { Number of seroreactive } \\
\text { dogs to Ehrlichia spp. } \\
(\%)^{\mathrm{a}}\end{array}$} & \multirow{2}{*}{ Ticks found in dogs ${ }^{a}$} \\
\hline & & $\mathrm{N}^{\circ} \cdot$ positive $(\%)$ & Related species & & \\
\hline Urban area & 160 & $25(15.6)$ & E. canis & $119(74.3)$ & R. sanguineus, $A$. cajennense \\
\hline Farm 1 & 06 & 0 & - & 0 & - \\
\hline Farm 2 & 17 & 0 & - & $13(76.4)$ & $R$. sanguineus, $A$. cajennense \\
\hline Farm 3 & 10 & 0 & - & $7(70.0)$ & A. cajennense \\
\hline Farm 4 & 09 & $1(11.1)$ & E. canis & $8(88.8)$ & $R$. sanguineus, $A$. cajennense \\
\hline Farm 5 & 07 & $1(14.2)$ & E. canis & $7(100.0)$ & R. sanguineus, $A$. cajennense \\
\hline Farm 6 & 04 & $1(25.0)$ & E. canis & $3(75.0)$ & $R$. sanguineus, $A$. cajennense \\
\hline Farm 7 & 08 & $4(50.0)$ & E. canis & $7(87.5)$ & $R$ sanguineus, $A$. cajennense \\
\hline Farm 8 & 04 & $2(50.0)$ & E. canis & $4(100.0)$ & - \\
\hline Farm 9 & 04 & $1(25.0)$ & E. canis & $3(75.0)$ & R. sanguineus, $A$. cajennense \\
\hline Farm 10 & 06 & $1(16.6)$ & E. canis & $2(3.3)$ & A. cajennense \\
\hline Farm 11 & 04 & $1(25.0)$ & E. canis & $2(50.0)$ & - \\
\hline Farm 12 & 04 & 0 & - & $2(50.0)$ & R. sanguineus \\
\hline Farm 13 & 02 & 0 & - & $1(50.0)$ & $R$ sanguineus \\
\hline Farm 14 & 02 & 0 & - & 0 & $R$ sanguineus \\
\hline Farm 15 & 05 & $2(40.0)$ & E. canis & $5(100.0)$ & $R$. sanguineus \\
\hline Farm 16 & 05 & 0 & - & $4(80.0)$ & A. cajennense \\
\hline Farm 17 & 02 & 0 & - & $2(100.0)$ & - \\
\hline Farm 18 & 01 & 0 & - & 0 & A. cajennense \\
\hline Farm 19 & 03 & 0 & - & 0 & A. cajennense \\
\hline Farm 20 & 02 & 0 & - & $2(100.0)$ & A. cajennense \\
\hline Farm 21 & 03 & 0 & - & $1(33.3)$ & A. cajennense \\
\hline Farm 22 & 02 & 0 & - & $1(50.0)$ & A. cajennense \\
\hline Farm 23 & 03 & 0 & - & $1(33.3)$ & A. cajennense, $A$. ovale \\
\hline Farm 24 & 03 & 0 & - & $2(66.6)$ & A. cajennense, $A$. ovale \\
\hline Farm 25 & 02 & 0 & - & $1(50.0)$ & A. cajennense \\
\hline Community 1 & 22 & $3(13.6)$ & E. canis & $12(54.5)$ & R. sanguineus, $A$. cajennense, $A$. ovale \\
\hline Community 2 & 09 & $2(22.2)$ & E. canis & $9(100.0)$ & $R$. sanguineus, $A$. cajennense \\
\hline Community 3 & 11 & $4(36.3)$ & E. canis & $9(81.8)$ & R. sanguineus, A. cajennense, A. ovale \\
\hline
\end{tabular}

${ }^{2}$ According to Melo et al. (2011); No - number; \% - percentage.

Despite the recent reports of ehrlichial agents other than E. canis in Brazil (MACHADO et al., 2006; SILVEIRA et al., 2012; ANDRÉ et al., 2010, 2012; SACCHI et al., 2012), molecular detection of new genotypic variants in Brazilian wildlife animals has been reported, since those animals play the role of sentinels for vector-borne pathogens because they can act as hosts for both bacteria and arthropod, including wildlife of the Pantanal region (WIDMER et al., 2011). However, the present work failed to detect Ehrlichia species different from $E$. canis infecting dogs from northern Pantanal, even though we used a high sensitive PCR capable of detecting all known Ehrlichia species (LABRUNA et al., 2007). These data corroborated previous studies that reported E. canis as the only Ehrlichia species that has been isolated in vitro from dogs in Brazil (AGUIAR et al., 2007, 2008; TORRES et al., 2002).

\section{Acknowledgements}

This work was supported by 'Fundação de Amparo à Pesquisa do Estado de Mato Grosso' (FAPEMAT) and 'Conselho Nacional de Desenvolvimento Científico e Tecnológico' (CNPQ). Scholarships were provided by 'Coordenação de Aperfeiçoamento de Pessoal de Nivel Superior' (CAPES) to LGFS and ALTM, by FAPEMAT to RW, and by CNPQ to MBL and DMA.

\section{References}

Aguiar DM, Cavalcante GT, Pinter A, Labruna MB. Prevalence of Ehrlichia canis (Rickettsiales: Anaplasmataceae) in dogs and Rhipicephalus sanguineus (Acari: Ixodidae) ticks from Brazil. J Med Entomol 2007(1); 44:126-132. http://dx.doi.org/10.1603/00222585(2007)44[126:POECRA]2.0.CO;2

Aguiar DM, Hagiwara MK, Labruna MB. In vitro isolation and molecular characterization of an Ehrlichia canis strain from São Paulo, Brazil. BrazJ Microbiol2008; 39(3): 489-493. http://dx.doi.org/10.1590/ S1517-83822008000300014

Alho CJR, Lacher Júnior TE, Campos ZMS, Gonçalves HC. Mamíferos da Fazenda Nhumirim, sub-região de Nhecolândia, Pantanal do Mato Grosso do Sul. I - Levantamento preliminar de espécies. Rev Bras Zool 1987; 4(2): 151-164. http://dx.doi.org/10.1590/S010181751987000200007 
Almeida AP. Pesquisa de Rickettsia, Ehrlichia, Anaplasma, Babesia, Hepatozoon e Leishmania em Cachorro-do-mato (Cerdocyon thous) de vida livre do Estado do Espirito Santo. [Thesis] São Paulo: Universidade de São Paulo; 2011.

Allsopp MTEP, Allsopp BA. Novel Ehrlichia Genotype Detected in Dogs in South Africa. J Clin Microbiol 2001; 39(11): 42044207. PMid:11682562 PMCid:88519. http://dx.doi.org/10.1128/ JCM.39.11.4204-4207.2001

Altschul SF, Gish W, Miller W, Myers EW, Lipman DJ. Basic local alignment search tool. J Mol Biol 1990; 215(3): 403-410. PMid:2231712.

André MR, Adania CH, Machado RZ, Allegretti SM, Felippe PAN, Silva KF, et al. Molecular and Serologic Detection of Ehrlichia spp. in Endangered Brazilian Wild Captive Felids. J. Wildl Dis 2010; 46(3): $1017-$ 1023. PMid:20688716.

André MR, Dumler JS, Scorpio DG, Teixeira RHF, Allegretti SM, Machado RZ. Molecular detection of tick-borne bacterial agents in Brazilian and exotic captive carnivores. Ticks Tick Borne Dis 2012; 3(4): 247-253. PMid:22749737. http://dx.doi.org/10.1016/j. ttbdis.2012.04.002

Bechara GH, Szabó MP, Duarte JM, Matushima ER, Pereira MC, Keirans JE, et al. Ticks associated with wild animals in the Nhecolândia Pantanal, Brazil. Ann NY Acad Sci 2000; 916: 289-297. PMid:11193635. http:// dx.doi.org/10.1111/j.1749-6632.2000.tb05303.x

Doyle CK, Labruna MB, Breitschwerdt EB, Tang YW, Corstvet RE, Hegarty BC, et al. Detection of Medically Important Ehrlichia by Quantitative Multicolor TaqMan Real-Time Polymerase Chain Reaction of the dsb Gene. J Mol Diagn 2005; 7(4): 504-510. http://dx.doi. org/10.1016/S1525-1578(10)60581-8

Dumler JS, Barbet AF, Bekker CP, Dasch GA, Palmer GH, Rikihisa $\mathrm{Y}$, et al. Reorganization of genera in the families Rickettsiaceae and Anaplasmataceae in the order Rickettsiales: unification of some species of Ehrlichia with Anaplasma, Cowdria with Ehrlichia and Ehrlichia with Neorickettsia, descriptions of six new species combinations and designation of Ehrlichia equi and 'HGE agent' as subjective synonyms of Ehrlichia phagocytophila. Int J Syst Evol Microbiol 2001; 51(6): 2145-2165. PMid:11760958. http://dx.doi.org/10.1099/00207713$51-6-2145$

Harrus S, Waner T. Diagnosis of canine monocytotropic ehrlichiosis (Ehrlichia canis): An overview. Vet J 2011; 187(3): 292-296. PMid:20226700. http://dx.doi.org/10.1016/j.tvjl.2010.02.001

Kelly PJ, Matthewman LA, Mahan SM, Semu S, Peter T, Mason PR, et al. Serological evidence for antigenic relationships between Ehrlichia canis and Cowdria ruminantium. Res Vet Sci 1994; 56(2): 170-174. http:// dx.doi.org/10.1016/0034-5288(94)90100-7

Labruna MB, McBride JW, Camargo LM, Aguiar DM, Yabsley M.J, Davidson WR, et al. A preliminary investigation of Ehrlichia species in ticks, humans, dogs, and capybaras from Brazil. Vet Parasitol 2007; 143(2):189-195. PMid:16962245. http://dx.doi. org/10.1016/j.vetpar.2006.08.005

Machado RZ, Duarte JM, Dagnone AS, Szabó MP. Detection of Ehrlichia chaffeensis in Brazilian marsh deer (Blastocerus dichotomus). Vet Parasitol 2006; 139(1-3): 262-266. PMid:16621285. http://dx.doi. org/10.1016/j.vetpar.2006.02.038

McBride JW, Walker DH. Progress and obstacles in vaccine development for the ehrlichioses. Expert Rev Vaccines 2010; 9(9): 1071-1082. PMid:20822349 PMCid:2951016. http://dx.doi.org/10.1586/erv.10.93

Melo ALT, Martins TF, Horta MC, Moraes-Filho J, Pacheco RC, Labruna $\mathrm{MB}$, et al. Seroprevalence and risk factors to Ehrlichia spp. and Rickettsia spp. in dogs from the Pantanal Region of Mato Grosso State, Brazil. Ticks Tick Borne Dis 2011; 2(4): 213-218. PMid:22108015. http://dx.doi. org/10.1016/j.ttbdis.2011.09.007

Sacchi ABV, Duarte JMB, André MR, Machado RZ. Prevalence and molecular characterization of Anaplasmataceae agents in free-ranging Brazilian marsh deer (Blastocerus dichotomus). Comp Immunol Microbiol Infect Dis 2012; 35(4): 325-334. PMid:22381686. http://dx.doi. org/10.1016/j.cimid.2012.02.001

Silveira JAG, Rabelo EML, Ribeiro MFB. Molecular Detection of Tick- Borne Pathogens of the Family Anaplasmataceae in Brazilian Brown Brocket Deer (Mazama gouazoubira, Fischer, 1814) and Marsh Deer (Blastocerus dichotomus, Illiger, 1815); Transbound Emerg Dis; 2012; 59(4):353-360. PMid:22136597. http://dx.doi.org/10.1111/ j.1865-1682.2011.01278.x

Torres HM, Massard CL, Figueiredo MJ, Ferreira T, Almosny NRP. Isolamento e propagação da Ehrlichia canis em células DH82 e obtenção de antígeno para a reação de imunofluorescência indireta. Rev Bras Cienc Vet 2002; 9(2): 77-82.

Vieira RFC, Biondo AW, Guimarães MAS, Santos AP, Santos RP, Dutra LH, et al. Ehrlichiosis in Brazil. Rev Bras Parasitol Vet 2011; 20(1): 1-12. PMid:21439224. http://dx.doi.org/10.1590/ S1984-29612011000100002

Widmer CE, Azevedo FC, Almeida AP, Ferreira F, Labruna MB. Tickborne bacteria in free-living jaguars (Panthera onca) in Pantanal, Brazil Vector Borne Zoonotic Dis. 2011; 11(8): 1001-1005. http://dx.doi. org/10.1089/vbz.2011.0619 